\title{
ANDRZEJ OLUBiŃSKI
}

\section{ROLA NAUK PEDAGOGICZNYCH W REFORMOWANIU RZECZYWISTOŚCI I ULEPSZANIU LUDZKIEGO ŻYCIA (NA PRZYKŁADZIE FUNKCJONOWANIA SZKOLNICTWA WYŻSZEGO)}

\begin{abstract}
Abstrakt: Artykuł skupia się na działaniu instytucji szkolnictwa wyższego w kontekście celów i funkcji przypisanych im w obszarze edukacji i badań. W pierwszej części autor omawia podstawowe cele i funkcje współczesnej edukacji, przyjęte przez Unię Europejską, które są opisane przez J. Delorsa w powszechnie znanym raporcie. Cele te podkreślają humanistyczne wartości edukacji. Następnie autor skupia się na źródłach i objawach kryzysu, który ma wpływ na szkolnictwo wyższe w Polsce. Omawia również dysfunkcje edukacji i badań naukowych przeprowadzanych w instytucjach szkolnictwa wyższego. Jego zdaniem dysfunkcje te manifestują się na wiele sposobów, np. utratą autorytetu przez nauczycieli, narzucaniem praw gospodarki rynkowej przedsięwzięciom edukacyjnym i naukowym, dominacją encyklopedycznego przekazu wiedzy i uczenia się jej w tej formie, rosnącą biurokracją, utratą autonomii, promowaniem ustępstw i modelem „wyścigu szczurów”, itd. Autor twierdzi, że badania naukowe stają się coraz bardziej kontrolowane przez państwo, czego efektem jest dostosowywanie wyników badań do narzuconych przez państwo kryteriów oraz ich diagnostyczny i abstrakcyjny charakter. Podsumowanie zawiera nawołanie do radykalnej reformy szkolnictwa wyższego oraz promowania reformatorskich i przełomowych badań w działaniu.
\end{abstract}

Słowa kluczowe: edukacja, reforma, kryzys w edukacji, szkoła wyższa, reformowanie

\section{ELEMENTARNE CELE I FUNKCJE WSPÓŁCZESNEJ EDUKACJI}

Ogólne uwagi na temat elementarnych celów i funkcji współczesnej edukacji, w tym edukacji w szkole wyższej, należałoby odnieść do raportu J. Delorsa, w polskiej wersji opublikowanego pt. Edukacja. Jest w niej ukryty skarb (1998). Raport ten, 
napisany dla UNESCO pod koniec lat 90. XX, w dużym stopniu do chwili obecnej odzwierciedla opinie tej organizacji, a zwłaszcza Komisji Europejskiej, co do zasadniczych kierunków myślenia o roli edukacji we współczesnym świecie, a szczególnie o stałym rozwoju jednostki i społeczeństwa, w tym również doniosłej funkcji edukacji w likwidacji głównych problemów współczesnego świata.

Przede wszystkim według J. Delorsa współczesną edukację należałoby rozumieć jako formę optymalizującą ludzki rozwój oraz jako proces mający na celu poszerzenie możliwości człowieka. Możliwości te wydają się niemal nieograniczone i zmieniają się z biegiem czasu. Jednak dla jednostki w istocie najważniejsze są trzy cele, tj.: długie i zdrowe życie, zdobywanie wiedzy oraz dostęp do zasobów zapewniających poziom życia optymalizujący wszechstronny rozwój. Wśród innych możliwości, którym ludzie przypisują ważne znaczenie, dalej wymienić można: wolność polityczną, społeczną i ekonomiczną, przejawianie kreatywności jak również godność osobistą i poszanowanie praw człowieka, dostęp do edukacji, sprawiedliwość i równość społeczną, stopień demokratycznego uczestnictwa. Wszystkie te możliwości byłyby jednak nie do spełnienia, gdyby nie świadomość kierowania własnym rozwojem. W istocie zatem ostatecznym zadaniem edukacji wydaje się uświadomienie potrzeby permanentnego samokształcenia w celu kierowania własnym, optymalnym rozwojem. Ale edukacja powinna umożliwiać każdemu człowiekowi decydowanie o swoim losie w taki sposób, aby mógł przyczyniać się również do postępu społeczeństwa, w którym żyje. Nie chodzi przy tym tylko o dostarczanie gospodarce kwalifikowanych pracowników, lecz również - a może przede wszystkim - o rozwijanie uzdolnień, umiejętności oraz możliwości rozwoju każdej jednostki. Ta humanistyczna idea kształcenia wynika z czterech podstawowych filarów kształcenia, tj.: 1) uczyć się, aby wiedzieć (tzn. zdobyć narzędzie rozumienia), 2) uczyć się, aby działać (tzn. aby móc oddziaływać na swoje środowisko), 3) uczyć się, aby żyć wspólnie (tzn. aby uczestniczyć i współpracować z innymi), 4) uczyć się, aby być prawdziwym człowiekiem (tamże, s. 85-99; por. Olubiński 2004, 2006).

Tak rozumiana edukacja musi być procesem trwającym przez całe życie. Wynika to zarówno z dynamicznie zmieniającej się rzeczywistości, za którą trzeba nadążyć; potrzeby uczestniczenia w społeczno-ekonomicznym rozwoju, potrzeby porozumienia i dialogu, pożytecznego spędzania wolnego czasu, jak i po prostu formy naturalnej socjalizacji w wychowującym społeczeństwie.

Według członków Komisji Europejskiej szeroko rozumiana edukacja ujmowana jest jako proces zdobywania wiedzy przez całe życie, a także proces swoiście rozumianej aktywności kulturalnej, w istocie zaś proces kształtowania się pełnego człowieka (jego wiedzy, umiejętności, działań i wartości) - powinna być istotnym elementem przeciwdziałania głównym problemom życia jednostki i społeczeństwa. 
Jakkolwiek roli edukacji w rozwoju społeczno-ekonomicznym nie można przeceniać, to zdaniem członków Komisji jawi się ona - obok innych czynników rozwoju - jako niepowtarzalna szansa przyspieszania przeobrażeń tudzież w wielu wypadkach wręcz rozstrzygania o poziomie i jakości życia jednostek oraz całych społeczeństw. Dzięki edukacji bowiem człowiek nie tylko zdobywa konieczną wiedzę oraz umiejętności, które umożliwią mu podjęcie określonych ról zawodowych, ale przede wszystkim uczy się żyć z innymi ludźmi, co nierzadko rzutuje na wszelkie inne obszary jego życiowej aktywności, zasadniczo decydując o pozycji oraz losach na całe życie.

Czy nasze uczelnie wyższe w określonym stopniu i zakresie są w stanie realizować zarysowane powyżej edukacyjne cele i funkcje, zwłaszcza w obliczu edukacyjnej niewydolności szkolnictwa niższych szczebli? Wydaje się to raczej mało prawdopodobne, ponieważ szkolnictwo wyższe jest elementem całego systemu edukacji, a zapełniająca mury uczelni młodzież jest przecież „produktem” dysfunkcji w tym zakresie kształcenia na poziomie podstawowym, gimnazjalnym oraz średnim. Ponadto wydaje się, że w obliczu licznych zadań i wymogów stricte naukowych, zawodowych oraz organizacyjnych, uniwersytety nie tylko nie rekompensują strat edukacyjnych ponoszonych na niższych etapach kształcenia, ale wręcz je dodatkowo pogłębiają. Jakie są najbardziej widoczne symptomy oraz uwarunkowania edukacyjnego kryzysu polskich uczelni?

\section{UCZELNIE WYŻSZE W EDUKACYJNYM KRYZYSIE}

Istnieje dość powszechne naiwne przekonanie, że w neutralizacji tudzież zahamowaniu różnorodnych edukacyjnych negatywnych zjawisk zasadniczą rolę powinna odgrywać szkoła wyższa, w tym szczególnie uniwersytet. Nominalnie przyczyniać się on bowiem powinien do rozwoju społeczeństwa, powinien służyć dobru społecznemu itd. Przede wszystkim jednak studia powinny być źródłem pełniejszego rozwoju osoby ludzkiej i w tym kontekście powinny odpowiednio przygotować absolwentów do pełnienia ważnych oraz odpowiedzialnych ról i obowiązków społeczno-zawodowych (Jaskot 2006).

Niestety jednak, jak sygnalizuje to m.in. Janusz Mastalski (Mastalski 2008, s. 9-13) również uczelnie wyższe, w tym także uniwersytety, przeżywają w Polsce poważny kryzys, który zagraża możliwości elementarnej realizacji zasygnalizowanych powyżej humanistycznych celów. Do widocznych symptomów tego kryzysu należą m.in.: 1. Dekonstrukcja etosu nauczyciela akademickiego. Dużo by o tym mówić. Ograniczę się zatem jedynie do stwierdzenia, iż współczesny wykładowca w coraz mniejszym stopniu jest dla młodzieży autorytetem, przewodnikiem 
i mistrzem, w coraz większym zaś intelektualną „maszyną” do przekazywania informacji ${ }^{1}$. 2. Postawa roszczeniowa studentów. Wydaje się, że coraz bardziej zatraca się granica pomiędzy obowiązkami a prawami studentów na rzecz wypaczonej wizji ogromu praw, przy minimum obowiązków. Na wielu uczelniach już bywa tak, że studenci nie wywiązując się z podstawowego obowiązku studiowania, mają pretensje tudzież nawet oskarżają wykładowców o to, że ci próbują egzekwować od nich jakąś wiedzę oraz kulturę bycia, zamiast od razu wydać im dyplom ukończenia studiów. Coraz częściej dochodzi w tym zakresie do gorszących scen, niemal odwrócenia ról, kiedy to student rozlicza nauczyciela z jego obowiązków, samemu nic w zamian nie robiąc. 3. „Merkantylizacja” studiów. Zagrożenie to wiąże się ze skrajnym uzależnieniem funkcjonowania uczelni od uzyskiwanych przez nią wyników ekonomicznych. Jest to zatem ciągła walka o liczbę studentów (a więc o pieniądze), co odbija się negatywnie na jakości kształcenia. Płatne studia oznaczają często ocenę dostateczną za samą „łaskę” pojawienia się studenta na egzaminie. W nieskończoność powiększa się również liczebność studentów w grupie ćwiczeniowej, itd. itp. W Polsce pojawiły się już uczelnie, którym głównie zależy na szybkim produkowaniu absolwentów, nie zaś ich kształceniu. 4. Brak konstruktywnej oraz stabilnej polityki oświatowej Państwa w zakresie szkolnictwa wyższego. Cechuje ją doraźność, krótkowzroczność, a głównie dążenie do coraz większej centralizacji procesu edukacji. Wprawdzie Sejm RP uchwalił właśnie nową Ustawę o szkolnictwie wyższym, jednak trudno na etapie wprowadzania reformy sądzić, w jakim stopniu jej zapisy zasadniczo odmienią jakość funkcjonowania szkolnictwa wyższego w Polsce. 5. Encyklopedyzm dydaktyczny, kładący nacisk na pamięciowe opanowanie opasłych podręczników (tudzież ich internetowych namiastek), zamiast przyswajania rzetelnej i pogłębionej wiedzy oraz kształtowania opartych o nią umiejętności. 6. Toksyczny model studiów wyższych, polegający na takiej organizacji studiów, głównie niestacjonarnych, aby zajęcia weekendowe skumulować w liczbie 10-12 godzin w ciągu dnia. W takiej liczbie prowadzone wykłady oraz ćwiczenia są, biorąc pod uwagę ich elementarną efektywność, po prostu usankcjonowaną fikcją. 7. Deprecjacja uczelni jako środowiska wychowawczego oraz relacji interpersonalnych. $Z$ wielu powodów proces kształcenia na uczelniach wyższych jest zaprzeczeniem podstawowej zasady dydaktycznej, tj. nauczania wychowującego, którego istota wyraża się w próbach połączenia przekazywania wiedzy z kształtowaniem postaw

\footnotetext{
${ }^{1} \mathrm{Na}$ temat roli autorytetu mistrza na uczelni wyższej zob. m.in.: K. Olbrycht, O roli przykła$d u$, wzoru, autorytetu i mistrza w wychowaniu osobowym, Toruń 2007; A. Olubiński, Rola autorytetu mistrza w procesie rozwijania humanistycznej edukacji, [w:] tenże (red.), Autorytet. Czy potrzebny w procesie edukacji?, Toruń 2010, s. 217-233; A. Szeląg (red.), Problemy edukacji w szkole wyższej, Kraków 2006.
} 
i wartości, co sprzyja rozwojowi psychofizycznemu młodego człowieka. Edukacja pozbawiona jest ponadto podejścia indywidualnego, a student traktowany jest w sposób anonimowy, ilościowy oraz rzeczowy. Proces kształcenia ma charakter głównie monologu, a nie dialogu mistrza oraz ucznia jako podstawy wzajemnego rozwoju osobowości.

Ponadto wielu przedstawicieli nauk społecznych zwraca uwagę m.in. na fakt, iż szkolnictwo wyższe, jak gdyby mechanicznie dostosowując się do skrajnie liberalnych trendów zmian w sferze modelu ładu gospodarczego, wyraźnie przekształca się z instytucji naukowej, kulturotwórczej oraz edukacyjnej w przedsiębiorstwo, a nawet $\mathrm{w}$ „,uniwersy tet przemysłowy”. M. Czerepaniak-Walczak wręcz stwierdza, że w coraz większym stopniu i zakresie edukacja i badania naukowe stają się tutaj swoiście rozumianą produkcją, a wyniki badań, ale również absolwenci jako ludzie stają się po prostu towarem. (M. Czerepaniak-Walczak 2001, s. 55 i n.) W ten sposób uczelnia wyższa, rozumiana jako przedsiębiorstwo przemysłowe oparte o reguły gry rynkowej, z natury rzeczy w coraz większym stopniu wypiera również tradycyjne wartości edukacyjne. Badania naukowe traktowane są często jako narzucone zadanie tudzież usługa do wykonania, jako źródło dodatkowych dochodów czy podniesienia pozycji w rankingach. Podobną rolę pełni organizacja studiów: powoływane kierunki i specjalności kształcenia, wymuszane przez rynek pracy oraz wymagane kwalifikacje, formułowane są przez poszczególne resorty czy wręcz korporacje zawodowe. Efektem tego jest kształtowanie postaw konformizmu, niekiedy również serwilizmu (politycznego), stojących w wyraźnej sprzeczności z tradycyjną rolą uniwersytetu jako źródła społecznego krytycyzmu. Badania oraz kształcenie wikła się zatem w mechanizmy swoiście rozumianej cenzury w doborze problemów badawczych czy treści kształcenia, tak by odpowiadały zapotrzebowaniu rynku czy wręcz oczekiwaniom sponsorów.

W tym kontekście należy sądzić, że tradycyjna kultura akademicka oraz autonomia oraz godność uniwersytetu w coraz większym stopniu wypierane są przez potrzebę zewnętrznej, politycznej oraz administracyjno-organizacyjnej poprawności, doraźnej lojalności (pod groźbą odpowiedniego ukarania - sic!) wobec administracji państwowej coraz bardziej centralizującej oraz kontrolującej funkcjonowanie uczelni². Taka koncepcja uczelni wyższej jako przedsiębiorstwa budzi opór ze strony zwolenników tradycyjnej jej misji. Należałoby dodać, iż opór ten nie dotyczy idei przedsiębiorczości jako takiej, rozumianej jako dążenie do podmiotowego zarządzania uczelnią, którą można traktować jako jeden z celów edukacji. Jedną z zasadniczych zatem cech uczelni przedsiębiorczej byłaby jej autonomia,

${ }^{2}$ Zob. na temat m.in. centralizacji szkolnictwa opracowanie B. Śliwerskiego pt. Diagnoza uspołecznienia publicznego szkolnictwa III RP w gorsecie centralizmu, Kraków 2013. 
także w zakresie podejmowanych problemów badawczych czy organizacji studiów, która zapisana jest zresztą w Prawie o szkolnictwie wyższym. Inną - wolność wspólnotowa, polegająca na dążeniu profesorów oraz studentów do realizacji powszechnego dobra.

Za ewidentny przykład „przedsiębiorczej” polityki Państwa wobec uczelni wyższych niech posłuży fakt spadających z roku na rok realnych nakładów na naukę, jednych z najniższych w Europie (obok Cypru, Łotwy czy Malty), niższych m.in. od Słowacji, Węgier, Litwy oraz Czech. Niepokojący jest tutaj również wewnętrzny podział tych skromnych środków. Dla przykładu: o ile od roku 2009 radykalnie ogranicza się środki na badania własne, to realny przyrost tego typu środków powiększył się praktycznie jedynie w dziedzinie nauk przyrodniczych (o ok. 11\%) kosztem nauk społeczno-humanistycznych (zob. Kryńska 2001, s. 70-71).

Niezależnie jednak od tak rażącej oraz nieodpowiedzialnej marginalizacji nauk społecznych, przy minimalnych nakładach środków w ogóle na szkolnictwo wyższe $(0,76 \%$ PKB, a powinnien być co najmniej $1 \%)$, zapewne także nauki przyrodnicze nie sprostają światowej konkurencyjności, nie mówiąc już o radykalnie obniżającej się jakości kształcenia niezależnie od studiowanego kierunku czy dyscypliny. Niska jakość kształcenia jest również funkcją dynamicznego wzrostu liczby studentów oraz szkół wyższych po roku 1990. Gdy w roku 1991 studiowało w Polsce ok. 400 tysięcy osób, dziś jest ich ok. 2 mln. Wskaźnik tzw. scholaryzacji wzrósł w tym czasie zatem z ok. 13 do 50\%. Z drugiej strony gdy liczba studentów zwiększyła się prawie 5-krotnie, liczba nauczycieli akademickich wzrosła niewiele ponad 60\%. Oznacza to, że obecnie na jednego nauczyciela przypada ok. 25-30 studentów, co zdecydowanie ogranicza bezpośrednią możliwość kontaktów profesora ze studentem. W praktyce profesora student jedynie widzi albo na wykładzie, albo na pisemnym egzaminie (i to też nie zawsze). Dochodzi do tego dodatkowe obciążenie nauczycieli akademickich dydaktyką (najczęściej na co najmniej dwóch etatach), która de facto daje im realne dochody finansowe, niestety nieporównywalnie większe niż zaangażowanie w pracę naukową oraz naukowe pisarstwo. Wszyscy wiemy np., że profesor mający ogromny dorobek, szerokie, międzynarodowe kontakty oraz naukowy autorytet, a także pracujący na jednym etacie, zarabia tyle samo lub nawet mniej niż jego kolega publikujący jeden artykuł rocznie, niewychylający nosa z macierzystej uczelni oraz pracujący na drugim lub nawet trzecim etacie w innych miejscach pracy (tamże, s. 71-72).

Jak była o tym mowa - w zasadzie w nowej Ustawie MNiSW na kolejne lata nie widać perspektywy jakichś radykalnych zmian poza chęcią zaoszczędzenia na szkolnictwie wyższym kolejnych finansów oraz poza propozycjami jeszcze większej kontroli oraz centralizacji funkcjonowania szkół wyższych. Wydaje się, że takie instrumentalne traktowanie uniwersytetów, przy coraz mniejszych nakładach 
na ich rozwój, w prostej linii prowadzi do ich uzawodowienia, schematyzacji, formalizacji, rutynizacji, itd., a więc produkowania rzemieślników, być może przydatnych na rynku pracy, lecz na pewno nie kreatywnych, otwartych na zmiany, a głównie realizujących misję kształtowania nowego, wielostronnie oraz optymalnie rozwiniętego człowieka. Jak pisze bowiem T. Bauman: „Szkoły wyższe będą in nowacyjne i otwarte na zmiany, jeżeli siłą sprawczą gruntownej naprawy będą one same, czyli będą agendami reform i będą kształciły reformatorów, będą tworzyły krytyczną świadomość wewnątrz społeczności akademickiej oraz społeczeństwa jako całości” (Bauman 2007, s. 175.).

\section{SZKOŁA WYŻSZA JAKO INSTYTUCJA FASADOWA, ADAPTACYJNA I SERWILISTYCZNA}

Tak zatem, biorąc pod uwagę obecny oraz planowany na najbliższe lata status uczelni wyższych w Polsce, odnosi się wrażenie, jak gdyby kształtowanie systemu edukacji, w tym szkolnictwa wyższego, cofało jego rozwój, nawiązując do negatywnych dla rozwoju społecznego reliktów przeszłości, o których chciałoby się jak najszybciej zapomnieć. Być może - jak pisze P. Sztompka - w naszym kraju swoisty stan zacofania szkolnictwa, w tym również szkolnictwa wyższego, m.in. wynika z tzw. niedokończonej rewolucji polegającej na reformach połowicznych, pozorowanych, ciągle kierowanych jeszcze przez ludzi uwikłanych w dawne PRL-owskie i PZPR-owskie układy, którym brak osobowościowych kompetencji oraz odpowiedniego systemu wartości do profesjonalnego sprawowania odpowiedzialnych funkcji społecznych, a którzy kierując się często nabytymi w poprzedniej epoce egocentryzmem, osobistymi korzyściami oraz kolesiowskimi układami - sieją spustoszenie kompetencyjne, organizacyjne, społeczne, moralne itd. Tego typu jeszcze dość powszechne postawy liderów życia społeczno-gospodarczego zdają się sprzyjać narastającym nastrojom społecznej frustracji, zniechęcenia oraz niewiary w sens aktywnego zaangażowania w przeobrażenia społeczne i budowanie społeczeństwa obywatelskiego. (Sztompka 2000, s. 89).

Innym grzechem współczesnej edukacji, w tym szkolnictwa wyższego, również charakterystycznym dla krajów zachodnich, wydaje się jej jednowymiarowy charakter tudzież zasadnicza przepaść dzieląca ją od realnej rzeczywistości. Jak piszą D.J. Greenwood i M. Levin w artykule pt. Reforma nauk społecznych i uniwersytetów przez badania interwencyjne, „[...] relacje uniwersytetów z kluczowymi elementami otoczenia społeczno-politycznego są ucieleśnieniem politycznie/ekonomicznie/samoniszczycielskiego zachowania. Wielu uniwersyteckich badaczy w naukach społecznych pisze o sobie i dla siebie, celowo angażując się najmniej, jak to 
możliwe, w publiczne debaty i w społecznie istotne sprawy. Często wyniki ich badań są opisywane w języku i z użyciem takich pojęć, że są niezrozumiałe dla ludzi, którzy są obiektami badań, a także dla tych na zewnątrz uniwersytetów, którzy być może chcieliby te rezultaty wykorzystać” (Greenwood, M. Levin 2009, s. 77). Szczególnie niepokoi autorów niewytłumaczalna przepaść pomiędzy naukami społecznymi a społeczeństwem. Starając się znaleźć odpowiedź na ten problem, formułują tezę, iż być może jest tak dlatego, że w istocie nadrzędną funkcją uniwersytetów jest reprodukcja różnic społecznych poprzez kształcenie, są badania - aby zapewnić nowym, uprzywilejowanym generacjom dostęp do kluczowych pozycji w strukturach władzy. Duża bowiem część tych badań jest finansowana z zewnątrz, co lokuje uczelnie jako usługobiorcę w relacjach z istniejącymi strukturami władzy; ale są one również w pewien sposób podporządkowane państwu (i jego doraźnym interesom - A.O.).

Podobną opinię formułuje w tym zakresie np. P. Bourdieu , który sądzi, że naukowcy są niechętni społecznej aktywności nakierowanej na zmienianie praktyki, a zamiast tego pozwalają sobie na zajmowanie pozycji i wspieranie ideologii często będących w otwartym konflikcie z teoriami i metodami, które sami stworzyli (tamże, s. 82-83; zob. też Bourdieu 2007, 2008).

Jaki zatem rodzaj wiedzy liczy się na współczesnych uniwersytetach? Jeśliby rozróżnić za Arystotelesem wiedzę na typu episteme jako klasyczny rodzaj wiedzy teoretycznej, wiedzę typu techne jako swoiście rozumianą wiedzę zorientowaną na kierowane z zewnątrz zmienianie praktyki (wiedzę typu know-how) oraz wiedzę typu phronesis jako swoisty projekt działania poprzez wspólne konstruowanie wiedzy wraz z uprawomocnionymi uczestnikami - to uniwersytety są niechętne nauczaniu typu właśnie techne, a głównie typu phronesis, ponieważ odwołuje się ona do potrzeb reform społecznych i ekonomicznych, przez co może drażnić podmioty sektora publicznego i prywatnego, w dużym stopniu zainteresowane status quo (Greenwood 2009, s. 88-89).

\section{W KIERUNKU EDUKACJI REFORMATORSKIEJ ORAZ BADAŃ KRYTYCZNO-INTERWENCYJNYCH}

Jest zatem mało prawdopodobne, że obecne programy kształcenia, nastawione na konkretny zawód, będą jednocześnie promowały ogólne cele uniwersytetu, polegające na kształceniu ludzi, aby zajmowali się zdobywaniem wiedzy, krytycznym myśleniem, a przede wszystkim uczestnictwem w pożądanych zmianach rzeczywistości. Rekonstrukcja uczelni prędzej czy później musi przejść z sytuacji koniecznej destrukcji tego, co było, oraz tego, co jest, w kierunku konstrukcji czegoś 
nowego. Taki nowy uniwersytet powinien próbować zorganizować się wokół zasad intelektualnego wzbogacania, sprawiedliwości społecznej czy społecznego postępu. Studenci musieliby widzieć swoją uczelnię jako nośnik służby publicznej, a nie jedynie zdobywania wiedzy dla wiedzy. Uczyliby się tego, jak rozwinąć własny umysł, jak przygotować się do zawodu, ale również jak zmienić warunki życia społeczności, społeczeństwa czy świata. Oczywiście taki zrekonstruowany uniwersytet musiałby wypracować sobie bardziej humanistyczny, pogłębiony oraz trafny system nagradzania za aktywność, osiągnięcia naukowe, dydaktyczne, a także organizacyjne (niż np. zdobywanie punktów), w którym nauczanie, upowszechnianie wiedzy oraz służba społeczna równałyby się badaniom i nauce. O wybitnych osiągnięciach decydowałyby zatem sukcesy w wielu obszarach aktywności, także - a może przede wszystkim - w tej typu phronesis. Również należałoby zmienić kryteria oceny rekrutacji osiągnięć kandydatów na studia. Zamiast zatem $\mathrm{np}$. średnich ocen $\mathrm{z}$ określonych przedmiotów, $\mathrm{w}$ dużym stopniu należałoby preferować określone osiągnięcia w działalności społecznej. Uczelnie nie mogą bowiem funkcjonować jako inkubatory dla przyszłych strażników status quo (Ladson-Billings, Donnor 2009, s. 422).

Wizję nowego uniwersytetu na poziomie uczelni reformatorskiej charakteryzuje m.in. Grace Boggs, która uważa, że taka edukacja musi spełniać następujące kryteria: 1. Opierać się na historii filozofii (antropologii), aby jednostki mogły zrealizować swój potencjał rozwojowy jako istoty ludzkie, aby miały głębokie i trwałe poczucie swojego życia jako nieustającej ewolucji ludzkiego gatunku oraz unikatowej zdolności istot ludzkich do kształtowania i tworzenia lepszej rzeczywistości. 2. Obejmować produktywną aktywność, w której ludzie wybierają cele i zadania i od początku do końca uczestniczą w ich realizacji. 3. Włączać się w istniejące sprzeczności oraz spory jako konieczne możliwości zdobywania doświadczenia dla rozwiązywania problemów własnego środowiska oraz przekształcania instytucji społecznych. 4. Obejmować jak najszerszą różnorodność zasobów i środowisk, także w edukacji pozaszkolnej - w różnorodnych środowiskach fizycznych i społecznych. 5. Obejmować rozwój cielesnej samowiedzy i dobrego samopoczucia. Studenci muszą dowiadywać się, jak zdrowo żyć i pracować, również po to, aby odwrócić antyludzkie warunki zdrowotne grup społecznie wykluczonych. 6. Obejmować jasno określone cele, również o charakterze politycznym: jak zdobyć władzę, aby lepiej rządzić (tamże, s. 423).

Jak mówi zatem cytowany powyżej P. Bourdieu, należałoby poszukiwać nowych rodzajów habitusu jako trwałych i przekładalnych dyspozycji do ustanawiania nowych struktur, nowej praktyki, zgodnej z pragnieniem swobodnego oraz kreatywnego działania. Apel o nowy rewolucyjny habitus zdaje się wynikać z uznania, że pole, w którym obecnie funkcjonują akademicy, ogranicza społeczne i intelektualne 
sprawstwo, które mogłoby nas zbliżyć do sprawiedliwości społecznej i ludzkiego wyzwolenia. „Wyzwaniem dla nas akademików, nie jest zatem sprawienie, aby ci spoza akademii byli bardziej podobni do nas, ale raczej uznanie pozaakademickich tożsamości, które musimy sami przyjąć, aby być bardziej użytecznymi dla interesów ludzi mogących wykorzystać nasze zdolności i umiejętności. Musimy nauczyć się czuć jak w domu na rogach (zaniedbanych) ulic i dzielnic [...], aby nasza praca wierniej odzwierciedlała problemy i interesy ludzi i społeczności" (Greenwood, Levin 2009, s. 425-426).

Należy odrzucić argumenty za oddzieleniem praktyki i teorii, także np. w badaniach społecznych. „Badania bez związku z praktyka są bowiem spekulacją” (tamże, s. 91). Przyjęcie zaś interwencyjnego modelu postępowania badawczego ściśle wiąże się z fundamentalnymi przemianami demokratycznymi oraz kluczową misją nauk społecznych. Badania w naukach społecznych muszą być współtworzone, zaś wiedza musi mieć charakter lokalny i profesjonalny. Wiedzę oraz badania można uznać za trafne, jeśli gwarantują działania w kierunku pożądanych zmian oraz rozwiązywania istotnych problemów społecznych.

Szczególnie przydatna w tym zakresie wydaje się strategia tzw. interwencyjnych badań jakościowych. W takim podejściu najważniejsze jest nie to, czy jakiś sposób spostrzegania świata stanowi „czystą” formę, a właśnie to, czy byłby dla ludzi sposobem nadawania sensu ich życiu, czy stanowi oparcie zarówno dla nich samych, jak i ich kulturowych praktyk, czy byłby podstawą ich rozumienia tego, jak należy postępować z ludźmi, czy wzbogaca ich twórczy charakter i umacnia pragnienie bycia wolnym i niezależnym. Przede wszystkim jednak humanistyczna orientacja $\mathrm{w}$ badaniach społecznych $\mathrm{z}$ natury rzeczy $\mathrm{w}$ większym stopniu zdaje się dostrzegać „ludzkie cechy” badanej populacji: jej godność, tożsamość, siłę sprawczą możliwych zmian itp. A zatem badania tego typu dokonują jak gdyby naturalnej selekcji wśród samych badaczy według kryterium możliwości dostrzeżenia przez nich podmiotu w przedmiocie swoich badań3 (Smith 2009, s. 159).

$\mathrm{W}$ procesie radykalnej zmiany paradygmatów badawczych wydaje się, że najostrzejsza zmiana następuje w jakościowych modelach badań konstruktywistycznych i uczestnicząco-fenomenologicznych, gdzie wykroczenie poza interpretację i rozumienie w kierunku działania społecznego jest prawdopodobnie jedną z najbardziej znaczących zmian ${ }^{4}$. Dla jednych działanie ma na celu przyciągnięcie

${ }^{3}$ Por. również w tym zakresie m.in. publikacje: K. Koneckiego 2000; D. Urbaniak-Zając i J. Piekarskiego 2001; D. Kubinowskiego 2010; P., Moustakasa 2001 i in.

${ }^{4}$ Tezę, iż programy badań pedagogicznych powinny iść w kierunku działania społecznego, D. Kubinowski określa mianem zwrotu pedagogicznego. Zob.: Od poznania do zmieniania. Czy „zwrot pedagogiczny" w praktykach badawczych nauk społecznych?, [w:] T. Bauman (red.), Praktyka badań pedagogicznych. Kraków 2013, s. 53-61. W moim przekonaniu tego typu „działaniowy” pa- 
liderów (wyzwolenie sił), dla innych stało się swoistym zobowiązaniem politycznym oraz etycznym. Kapitalną w tym rolę odgrywa kontrola społeczna, m.in. jako środek wspierania emancypacji, demokracji i wzmacniania społeczności, a także wyrównywania nierównowagi władzy, tak że ci wcześniej marginalizowani teraz uzyskują głos i stają się ludźmi (Guba, Lincoln 2009, s. 294 i n.). W tej konwencji badań prawda jest zatem uzgadniana, jest przedmiotem negocjacji, co będzie zaakceptowane jako prawda, jako rezultat dialogu i wspólnotowego sprawdzenia trafności przez argumentację uczestników w dyskursie. Kryteria trafności stanowić mogą zarówno uczciwość (jako np. fakt, iż wszystkie poglądy, żądania czy głosy powinny być widoczne w tekście), autentyczność ontologiczna lub (i) wychowawcza (jako np. kryteria podwyższonego poziomu świadomości), katalityczna oraz taktyczna (jako np. sprowokowanie ludzi do działania oraz do zaangażowania badacza do szkolenia uczestników badania), jak i postawa sprzeciwu oraz poststrukturalnej transgresji wobec istniejącego status quo, jako swoistej reakcji etycznej. Dużą rolę może tutaj odegrać tzw. refleksyjność badacza jako świadome doświadczanie siebie jako badacza, respondenta, nauczyciela i ucznia, jako kogoś poznającego siebie wewnątrz procesu samego badania. My nie tylko przenosimy "Ja” w teren, my również tworzymy „Ja" w terenie. Chodzi więc o „Ja” oparte na badaniu, "Ja" wniesione oraz „Ja” utworzone sytuacyjnie. Każde z tych „Ja” w procesie badań włącza się w grę scenariusza badań, posiadając konsekwentnie odrębny głos. Ale krytyczne badania jakościowe to m.in. np. zapisywanie (notatki z terenu), opisywanie (narracja), ale w dużym stopniu to również pisanie jako proces odkrywania przedmiotu oraz odkrywania „Ja” (tamże, s. 302-303).

De facto zatem krytyczne jakościowe badania w naukach społecznych jawią się jako bunt przeciwko pozytywizmowi, przeciwko tezie, że techniki badawcze mogą stworzyć bezstronny, obiektywny punkt widzenia. Tego typu badacze (np. etnografowie krytyczni) zaczęli cenić sobie np. introspekcję, pracę pamięciową, autobiografię czy analizę snów jako ważne sposoby poznawania rzeczywistości. Wielu etnografów np. dowodzi, że w państwach politycznie skorumpowanych oraz niesprawiedliwych (niezależnie od formalnego ustroju politycznego) środki wiodące do tego, aby znaleźć „sprawcę”, mogą być uznane za uzasadnione, jeśli pokazują szkodliwe praktyki społeczne. Państwo bowiem jak gdyby z natury rzeczy reprodukuje nierówności społeczne czy edukacyjne, inteligentnie to ukrywając. W tym kontekście uczelnia wyższa powinna głównie nagradzać „obywateli-naukowców”, którzy pomagają lokalnej społeczności dojść do jej tożsamości, wyzwolenia oraz emancypacji (Kincheloe 2009, s. 335\}.

radygmat badawczy jest obecny w teorii klasycznej pedagogiki społecznej niemal od początku jej istnienia jako subdyscypliny naukowej. 
Zatem badacze społeczni muszą usytuować się tak, aby odegrać bardziej aktywną rolę w odkrywaniu, ujawnianiu czy demaskowaniu różnorodnych niesprawiedliwości, ale również w walce o równość i sprawiedliwość społeczną. Ich prace muszą także przekraczać wąskie granice dyscyplin. Niestety zdecydowanie zbyt wielu naukowców spędza czas, rozmawiając ze sobą w krainie umarłych akademii (Ladson-Billings, Donnor 2009, s. 420).

Teoria krytyczna kwestionuje więc założenie, że supernowoczesne i bogate społeczeństwa są w sposób nierodzący wątpliwości wolne i demokratyczne. Wydaje się, że wiele dotychczasowych badań w zakresie np. edukacyjnej sprawiedliwości miało, ale i nadal ma charakter wyraźnie stronniczy, preferując tzw. neutralne podejście do badań jako naukowy standard kultury akademickiej.

Nowe podejście do rozumienia nauki musi wyłonić grupę krytycznych badaczy, tj. tych, którzy będą próbować używać swej pracy jako formy społecznej krytyki i którzy zaakceptują konkretne założenia typu np.: że wszelka myśl jest zapośredniczona przez społecznie i historycznie kształtowane stosunki władzy; że fakty nie mogą być nigdy oderwane od dziedziny wartości lub pewnych inklinacji ideologicznych; że związki pomiędzy pojęciem a przedmiotem oraz pomiędzy znaczącym a znaczonym nigdy nie są stałe i niezmienne, często nawet są zapośredniczone przez relacje społeczne właściwe wolnorynkowemu systemowi produkcji i konsumpcji; że język jest kwestią podstawową w formowaniu subiektywności (świadomej i nieświadomej); że pewne grupy w społeczeństwie są uprzywilejowane względem innych, choć przyczyny tego uprzywilejowania mogą się znacznie różnić; że opresja charakteryzująca współczesne społeczeństwa jest najsilniej reprodukowana wtedy, gdy sami uprzywilejowani akceptują swój status jako naturalny, niezbędny i nieunikniony; że ucisk ma niejedno oblicze i że skupienie się na jednym z nich kosztem innych pomija związki między nimi; wreszcie że praktyki badawcze głównego nurtu stają się na ogół, choć najczęściej bezwiednie, narzędziami reprodukcji systemu klasowego, rasowego i genderowego (Kincheloe 2009 , s. 432-432).

Uczelnia wyższa promująca krytyczne badania interwencyjne jednocześnie opowiada się za zaangażowaniem w próby połączenia szerszych analiz społecznych ujawniających nierówności i niesprawiedliwości w społeczeństwie, z działaniem na rzecz zmiany tego stanu rzeczy. Oczywiście projektowanie oraz wspieranie badań interwencyjnych, dążących do transformacji istniejących sposobów rozumienia praktyk społecznych i sytuacji, musi mieć również na celu zmienianie ludzi i instytucji, które niekoniecznie muszą naturalnie uczestniczyć w procesie badania i działania. Chodzi tutaj o traktowanie takich badań jako praktyki, poprzez którą ludzie mogą tworzyć sieci komunikowania, tzn. warunki do praktykowania działania komunikacyjnego. Badania interwencyjne dążą do wywołania praktycznej krytyki status 
$q u o$, rozwoju krytycznych poglądów oraz podzielanego ukształtowania zaangażowania emancypacyjnego, takiego które przezwycięży zniekształcone (tj. np. niesprawiedliwe) rozumienie świata, praktyki, sytuacji społecznych czy warunków życia ludzi (zob. Kemmis, McTaggart 2009, s. 802-803). Wyniki takich badań muszą pokazywać inną rzeczywistość jako możliwą. $Z$ tej perspektywy istniejące struktury systemowe i różnorodne funkcje jawią się nie jako źródło przymusu i zniewolenia, ale jako możliwości zmiany na lepsze. Chodzi o to, aby nowe podejście do badań kształtowało interwencyjną świadomość zbiorowego działania, a także zbiorowego tworzenia i przekształcania historii (tamże, s. 824). Przyjmuje się tutaj bowiem założenie, że możliwości radykalnych i pożądanych zmian są immanentną częścią zbiorowej mądrości oraz zdolności. Uniwersyteccy badacze powinni zatem tak projektować swoje badania, aby wyłaniać oraz angażować w zmiany liderów społeczności lokalnych, z którymi współpraca prowadziłaby do rozwinięcia zbiorowej zdolności do zmiany okoliczności i warunków ich życia. Tego typu badania powinny redukować światowe zasoby irracjonalności, niesprawiedliwości, nierówności, braku satysfakcji i nieproduktywności: powinny angażować się w obronę pokoju oraz uniwersalnych praw człowieka (Denzin, Lincoln 2009, s. 38).

Zatem relacje pomiędzy badaczami, uniwersytetami a społeczeństwem muszą ulec zmianie. Politycznie przemyślane badania interwencyjne, zorientowane na praktykę i zmianę społeczną, to podstawa uprawiania nauki społecznie zorientowanej (tamże, s. 56). Badacze i społeczności powinny wspólnie definiować cele polityczne i cele badań, współkonstruować pytania badawcze, uzgadniać interpretację wyników oraz sposoby wdrożeń zmian praktycznych, oceniać ich efekty, trafność oraz wiarygodność poprzez gotowość lokalnych partnerów do dalszego działania.

\section{ZAKOŃCZENIE}

Możliwość uratowania setek tysięcy żywotnych sił narodu poprzez włączenie ich w system szeroko pojętej edukacji wynika nie tylko, a może nawet nie przede wszystkim, z faktu iż nauczą się one liczyć, pisać czy nawet rozumieć otaczający ich świat - ale przede wszystkim z faktu, iż edukacja jest również doświadczeniem społecznym. Dzięki niemu uczeń wzbogaca swoje stosunki z innymi ludźmi,

\footnotetext{
${ }^{5}$ Poglądy różnych autorów zachodnich na edukacyjną rolę współczesnej szkoły wyższej, zawarte w dwutomowym podręczniku pt. The Sage Handbook of Qualitative Research, omawia D. Kubinowski, określając je mianem zwrotu pedagogicznego (2013). W moim przekonaniu nie jest to zwrot, a raczej powrót do źródeł oraz specyfiki pedagogiki jako nauki krytyczno-praktycznej, zwłaszcza w jej społecznej wersji.
} 
zdobywa niezbędną w tym zakresie wiedzę oraz umiejętności. Edukacja i szkoła powinny również umieć odpowiedzieć na podstawowe pytania typu: w jakim celu żyć wspólnie, jak przygotować ludzi do aktywnego uczestnictwa w urzeczywistnianiu demokratycznego społeczeństwa. Zatem to co się dzieje w szkole, z natury rzeczy musi być również wzorem demokratycznej praktyki.

Jak najszybciej należy także wykryć przeszkody utrudniające dzieciom i młodzieży dostęp do rzetelnej edukacji. Trzeba by - zwłaszcza w stosunku do takich upośledzonych społecznie grup - wprowadzać politykę pozytywnej dyskryminacji. Trzeba w takich sytuacjach uruchamiać określone metody kompensacji braków rozwojowych; trzeba stosować specjalne oraz dodatkowe środki dydaktyczno-wychowawcze, także w placówkach pozaszkolnych itd. Wszystkie te działania muszą jednak dokonywać się w sposób zintegrowany, w ramach systemu tradycyjnego czy typowego, aby unikać tworzenia gett czy separacji nauczania „grup gorszych". Należałoby również starać się zmniejszać zjawisko odpadu i niepowodzeń, a także opuszczania systemu szkolnego bez kwalifikacji. Należałoby wreszcie przewidzieć sposoby uznawania i uzupełniania wykształcenia, tak aby młodzi ludzie, którzy wchodzą na rynek pracy bez określonych kwalifikacji zawodowych, w każdej chwili mogli je zdobyć poprzez inne pozaformalnoszkolne formy kształcenia.

W procesie uzdrawiania wychowującego społeczeństwa zdecydowanie większą niż dotychczas rolę musi odgrywać szkolnictwo wyższe ze społecznie zorientowanymi badaniami naukowymi. Uniwersytety nie mogą zamykać się we własnych murach pod pozorami „konieczności tworzenia prawdziwej wiedzy”. Zarówno programy, metody oraz sposoby kształcenia, jak i ściśle powiązane z nimi problemy oraz metodologia badań - muszą być bliżej rzeczywistości, którą dzięki krytycznej oraz aktywnej diagnozie należałoby nieustannie ulepszać w imię realizacji humanistycznych celów oraz wartości.

Oczywiście do wszystkich tego rodzaju czy tym podobnych działań niezbędna wydaje się zasadnicza wola polityczna (tudzież profesjonalizacja systemu rządzenia oraz sprawowania władzy), jednoznacznie wspierająca narodową strategię przeobrażeń edukacyjnych oraz sensowną całościową regulację systemu edukacyjnego (w tym zarezerwowanie odpowiednich środków finansowych). Jednoznaczne stanowisko Państwa i Rządu w złożonym procesie uspołeczniania edukacji oraz badań naukowych wydaje się tutaj konieczne.

Jak starano się bowiem wykazać w niniejszej publikacji, w dzisiejszym świecie rzetelny oraz na wysokim poziomie, społecznie zorientowany system edukacyjny, również na poziomie szkoły wyższej, wraz ze ściśle powiązanym z nim krytyczno-interwencyjnym oraz humanistycznie zorientowanym modelem uprawiania nauki należałoby uznać za jeden z najważniejszych warunków nie tylko redukowania 
zjawisk społecznej niesprawiedliwości oraz marnotrawienia żywotnych sił narodu, lecz przede wszystkim za zasadniczy czynnik postępowych przemian społeczno-ekonomicznych, bez których żaden naród nie ma szans na tworzenie humanistycznych wartości.

\section{LITERATURA}

Bauman T. (2007). Uniwersytet. W: T. Pilch (red.). Encyklopedia pedagogiczna XXI wieku. Warszawa.

Bauman T. (red.) (2013). Praktyka badań pedagogicznych. Kraków.

Bordieu P. (2007). Szkic teorii i praktyki. Kęty.

Bordieu P. (2008). Zmysł praktyczny. Kraków.

Cervinkowa H., Gołębniak B.D. (red.) (2010). Badania w działaniu. Pedagogika i antropologia zaangażowane. Wrocław.

Czerepaniak-Walczak M. (2001). Uniwersytet - instytucja naukowo-eduakcyjna czy przedsiębiorstwo ? Szkoła wyższa w procesie zmiany. W: J. Piekarski, D. Urbaniak-Zając (red.). Innowacje w edukacji akademickiej. Szkolnictwo wyższe w procesie zmiany. Łódź.

Delors J. (1998). Edukacja. Jest w niej ukryty skarb. Warszawa.

Denzin N.K., Lincoln Y.S. (red.) (2009). Metody badań jakościowych. T. 1-2. Warszawa.

Górniewicz J. (red.) (2012). Między ideałem a codziennością. Wybrane współczesne konteksty szkolnictwa wyższego. Olsztyn.

Górniewicz J. (red.) (2012). Podmioty wyższej edukacji w perspektywie przemian. Olsztyn.

Greenwood D.J., Levin M. (2009). Reforma nauk społecznych i uniwersytetów przez badania interwencyjne. W: N.K. Denzin, Y.S. Lincoln (red.). Metody badań jakościowych. T. 1. Warszawa.

Guba E.G., Lincoln Y.S. (2009). Kontrowersje wokót paradygmatów, sprzeczności i wyłaniające sie zbieżności. W: N.K. Denzin, Y.S. Lincoln (red.). Metody badań jakościowych. T. 1. Warszawa.

Jaskot H.W. (red.) (2006). Wprowadzenie do pedagogiki szkoły wyższej. Szczecin.

Kemmis S., McTaggart R. (2009). Uczesniczące badania interwencyjne. Działania komunikacyjne i sfera publiczna. W: N.K. Denzin, Y.S. Lincoln (red.). Metody badań jakościowych. T. 1. Warszawa.

Kincheloe J.L., McLaren P. (2009). Teoria krytyczna i badania jakościowe. Rewizja W: N.K. Denzin, Y.S. Lincoln (red.). Metody badań jakościowych. T. 1. Warszawa. 
Konecki K. (2000). Studia z metodologii badań jakościowych. Teoria ugruntowana. Warszawa.

Kostkiewicz J., Domagała-Kręcioch A., Szymański M. (red.) (2011). Szkoła wyższa $w$ toku zmian. Diagnozy i konsultacje. Kraków.

Kryńska J.E. (2001). Uniwersytet - podmiot czy obiekt zmian?. W: J. Piekarski, D. Urbaniak-Zając (red.). Innowacje $w$ edukacji akademickiej. Szkolnictwo wyższe $w$ procesie zmiany. Łódź.

Kubinowski D. (2013). Od poznania do zmieniania. Czy „zwrot pedagogiczny” w praktykach badawczych nauk społecznych. W: T. Bauman (red.). Praktyka badań pedagogicznych. Kraków.

Kwieciński Z. (2000). Tropy - ślady - próby. Poznań - Olsztyn.

Ladson-Billings G., Donnor J. (2009). Krytyczna teoria rasy i jej znaczenie etyczne. W: N.K. Denzin, Y.S. Lincoln (red.). Metody badań jakościowych. T. 1. Warszawa. Mastalski J. (2008). Uniwersytet przyszłości. „Wychowanie na co Dzień” 7-8.

Moustakas P. (2001). Fenomenologiczne metody badań. Białystok.

Olbrycht K. (2007). O roli przykładu, wzoru, autorytetu i mistrza $w$ wychowaniu osobowym. Toruń.

Olubiński A. (2004). Edukacyjne źródła marginalizacji (uwagi na kanwie refleksji nad tzw. raportem Jacques'a Delorsa). „Wychowanie na co Dzień” 6.

Olubiński A. (2007). Emancypacyjna rola edukacji w społeczeństwie okresu transformacji (w aspekcie kształcenia akademickiego). „Wychowanie na co Dzień”, nr 1-2.

Olubiński A. (2010). Edukacja jako sprawowanie władzy. „Wychowanie na co Dzień” 3.

Olubiński A. (2012). Rola autorytetu mistrza w procesie rozwijania humanistycznej edukacji. W: A. Olubiński (red.). Autorytet. Czy potrzebny w procesie edukacji?. Toruń.

Piekarski J., Pilch T., Theissa W., Urbaniak-Zając D. (red.) (2001). Edukacja społeczna wobec problemów współczesnego człowieka i społeczeństwa. Łódź.

Piekarski J., Urbaniak-Zając D. (red.) (2010). Innowacje w edukacji akademickiej. Szkolnictwo wyższe w procesie zmian. Łódź.

Plummer K. (2009). Krytyczny humanizm i teoria queer. W: N.K. Denzin, Y.S. Lincoln (red.). Metody badań jakościowych. T. 1. Warszawa.

Silverman D. (2008). Prowadzenie badań jakościowych. Warszawa.

Smith J.K., Hodkinson P. (2009). Relatywizm, kryteria i polityka. W: N.K. Denzin, Y.S. Lincoln (red.). Metody badań jakościowych. T. 2. Warszawa.

Szerląg A. (red.) (2006). Problemy edukacji w szkole wyższej. Kraków.

Sztompka P. (2000). Trauma wielkiej zmiany. Społeczne koszty transformacji. Warszawa. 
Szymański M. (1996). Selekcyjne funkcje szkolnictwa a struktura społeczna. Warszawa.

Śliwerski B. (2013). Diagnoza uspołecznienia publicznego szkolnictwa III RP w gorsecie centralizmu. Kraków.

Urbaniak-Zając D., Piekarski J. (2001). Jakościowe orientacje w badaniach pedagogicznych. Łódź.

Walzer M. (2007). Sfery sprawiedliwości. Obrona pluralizmu i równości. Warszawa.

\title{
THE ROLE OF PEDAGOGICAL SCIENCES IN REFORMING REALITY AND IMPROVING
} HUMAN LIFE (EXEMPLIFIED BY THE FUNCTIONING OF HIGHER EDUCATION)

\begin{abstract}
This article focuses on the functioning of the institutions of higher education in the context of goals and functions attributed to them in the area of education and research. In the first part of the article the author discusses basic goals and functions of contemporary education adopted by the European Union and presented by J. Delors in his well-known report. These goals emphasize the humanistic values of education. In the subsequent part of the paper the author focuses on the sources and symptoms of the crisis that affects higher education in Poland. The author discusses dysfunctions of education and scientific research undertaken in the institutions of higher education. According to the author, these dysfunctions manifest in many forms such as the loss of teacher's authority, imposition of market economy laws on the educational and scientific activity, the dominance of encyclopedic teaching and learning, increasing bureaucracy, the loss of autonomy, promotion of servility and the rat race model, etc. The author is of the opinion that scientific research is becoming more and more state-controlled, the effect of which is its adaptive, service-oriented, diagnostic and abstract character. In his concluding remarks, the author calls for radical reform of higher education that could result in enhancing its autonomy, restoring the humanistic function of education, and promoting reformist and critical action research.
\end{abstract}

Key words: education, reform, crisis in education, further education, reforming 